\title{
A Comparison between Organic and Inorganic Selenium: 1. Effect on Body Weight, Laying Performance, Hatchability in Broiler Breeder
}

\author{
P.P. Mohanty ${ }^{1}$, N. Panda ${ }^{2 *}$, R.K. Swain ${ }^{2}$, N.C. Behura ${ }^{3}$, \\ P. Ray ${ }^{4}$, A.K. Sethi ${ }^{4}$ and S. Panigrahi ${ }^{5}$ \\ ${ }^{I}$ Department of Animal Nutrition, College of Veterinary Science, PVNRTVU, \\ Telangana, India \\ ${ }^{2}$ Department of Animal Nutrition, C.V.Sc. and A.H, O.U.A.T., Bhubaneswar, India \\ ${ }^{3}$ Department of Poultry Science, C.V.Sc. and A.H, O.U.A.T., Bhubaneswar, India \\ ${ }^{4}$ Department of Microbiology, C.B.Sc. \& H. O.U.A.T., Bhubaneswar, India \\ ${ }^{5}$ Department of Animal Genetics and Breeding, College of Veterinary Science, Khanapara, \\ Guwahati, India \\ *Corresponding author
}

\section{A B S T R A C T}

One hundred and forty four numbers of $40^{\text {th }}$ week-old coloured broiler breeder hens were randomly distributed into 6 dietary treatments with three replicates with 8 chicks per

Keywords

Deficiency,

Immunity,

Supplementation,

Performance

Article Info

Accepted:

04 April 2018

Available Online:

10 May 2018 replicate. The dietary treatments were: $\mathrm{T}_{1}$ (Control group): Basal diet; $\mathrm{T}_{2}$ : Basal diet with $0.3 \mathrm{ppm}$ of inorganic Se (SS-0.3); $\mathrm{T}_{3}$ : Basal diet with $0.6 \mathrm{ppm}$ inorganic selenium (SS0.6); $\mathrm{T}_{4}$ : Basal diet with $0.3 \mathrm{ppm}$ of organic selenium (SY-0.3); $\mathrm{T}_{5}$ : Basal diet with 0.6 ppm of organic selenium (SY-0.6); and $\mathrm{T}_{6}$ : Basal diet with $0.3 \mathrm{ppm}$ sodium selenite+0.3 ppm selenium yeast (SS-0.3+SY-0.3). The supplementation was continued for 12 weeks. The body weight, hen day egg production $(\%)$, hatchability $(\%)$ was recorded at $6 \mathrm{wk}$ interval. There was no significant difference in body weight, laying performance of broiler breeder hen between the treatments. Hatchability study in $52^{\text {nd }}$ week birds supplemented with both in organic and inorganic selenium groups showed significantly higher percentage control groups. No significant difference found in egg weight and other egg quality parameters. From the above experiment it was concluded that feeding of organic selenium at both the doses to the coloured broiler breeder hens improved the egg hatchability in comparison with inorganic selenium. Therefore it is recommended that $0.3 \mathrm{ppm}$ of organic selenium should be supplemented to the broiler breeder hen.

\section{Introduction}

Selenium is an essential trace element in poultry nutrition. The essentiality of selenium in poultry was first reported in the year 1957 for the prevention of exudative diathesis (Patterson et al., 1957). Selenium deficiency in poultry manifests itself in many diseases and dysfunctions including liver necrosis, muscular dystrophy, microangiopathy, exudative diathesis, pancreatic fibrosis, poor feathering, immune deficiency, reduced hatchability and many others (Edens, 1996). Low level of selenium supplementation causes 
delayed immune development in chick along with impaired feathering and subsequent energy loss leading to increased embryo and bird mortality and reduced egg production (Finch and Turner, 1996; Surai, 2000; Edens, 2002) and encephalomalacia. In poultry selenium deficiency is mainly related to its antioxidant property through the enzyme glutathione peroxidase (GSHPx). Selenium supplementation can be done in two forms organic and inorganic forms. Sodium selenite and sodium selenate are the two inorganic sources whereas selenium enriched yeast and plant derived selenomethionine provide the organic forms (Torrent, 1997). In June 2000, selenium yeast was approved by the USFDA (Federal Register, 2000) as a source of feed supplemented organic selenium for chickens. Organic selenium has shown many advantages over inorganic sources.

The main and foremost advantage is its bioavailability. Organic selenium can be utilised to synthesize selenoproteins and excess selenium can be stored in a protein pool for different applications. But in case of inorganic forms are utilised for synthesis of selenoproteins and the excess selenium is excreted. Secondly organic selenium improves the antioxidant properties by increasing the GSH-Px and tissue selenium concentration in comparison to inorganic sources (Payne and Southern, 2005). Thirdly organic selenium fails to undergo pro-oxidation unlike inorganic selenium as it already exists in an organic form (Mahan, 1995).

Though some literature is available for commercial broiler breeder birds in Indian content, but a few research works has been carried out in coloured broiler breeder hens in India to find the optimum requirement. The objective of this research was to evaluate the effect of inorganic and organic selenium on body weight, laying performance and hatchability of broiler breeder hen.

\section{Materials and Methods}

\section{Location of research work}

The present experiment was conducted at the Department of Animal Nutrition in collaboration with the Poultry Complex, Faculty of Veterinary Science and Animal Husbandry, Orissa University of Agriculture and Technology, Bhubaneswar. The details of the materials and methods followed are described below.

\section{Selections of birds and dietary treatments}

A total number of 144 synthetic coloured broiler breeder hens of 40 wk age were selected from the poultry farm of Orissa Veterinary College according to their production record. The synthetic broiler breeder birds were developed by the All India Coordinated Research Project (AICRP) on Poultry Improvement. Vaccination against Newcastle disease (R2B strain) was done 20 days prior to the beginning of the experiment.

\section{Experimental design}

All the selected breeder birds are randomly allocated to six dietary treatments. Each treatment group had 3 replicates containing 8 chicks ( 7 female and male) in each replicate. The birds were housed in different cages leaving a gap of two cages between groups. The birds were supplemented with inorganic or organic selenium for $12 \mathrm{wks}$ starting from $40^{\text {th }}$ to $52^{\text {nd }}$ wk of age.

\section{Selenium sources of the experiment}

In this research two selenium sources were taken, inorganic selenium (Sodium Selenite, HIMEDIA) and organic selenium. Selenium yeast was prepared by growing Saccharomyces cerevisiae (yeast cells) in Potato Dextrose Broth at $37^{\circ} \mathrm{C}$ in the 
Department of Microbiology, OUAT. Then $700 \mathrm{ppm}$ of sodium selenite was added and incubated in incubator shaker for $48 \mathrm{hrs}$ at 100 $\mathrm{rpm}$ at $30^{\circ} \mathrm{C}$ to get optimum yeast harvest which was centrifuged and filtered to collect the selenium yeast. Then it was oven dried at $40^{\circ} \mathrm{C}$ to collect the dry biomass.

\section{Parameters}

Body weight was recorded individually three times i.e. $40^{\text {th }}$ wk, $46^{\text {th }}$ wk and $52^{\text {nd }}$ wk by using a top pan electric weighing machine. Mortality, hen day egg production, hatchability were recorded up to $12^{\text {th }}$ week of study period. Egg quality parameters like egg weight, egg length, breadth, shell thickness, yolk weight, height, width and albumen weight, height, width were recorded at $40^{\text {th }}$ wk, $46^{\text {th }}$ wk and $52^{\text {nd }}$ wk to see the effect of selenium source.

\section{Statistical analysis}

The data obtained from the study were statistically analysed according to Snedecor and Cochran (1994) and tabulated. The data were also analysed for analysis of variance (ANOVA) and DMR test (Duncan, 1995) was used to test the difference between treatment means wherever necessary.

\section{Results and Discussion}

The importance of selenium in poultry is very much known and a good number of researches have been conducted during last 10yrs indicating the dietary form of selenium is a major determinant for its efficiency (Table 13).

In the present experiment two levels of inorganic selenium in the form of sodium selenite and two levels of organic selenium with including a mixed form were supplemented for a period of $12 \mathrm{wks}$ in the coloured broiler breeder bird.

\section{Body weight}

The body weight at $40^{\text {th }}$ week varies from 3009.24 to $3244.17 \mathrm{~g}$. In $46^{\text {th }}$ and $52^{\text {nd }}$ weeks there was some increase in the body weight in most of the groups. The body weight of the birds was not statistically significant among the supplemented groups and between the 3 periods of age. Yoon et al., (2007) and Rao et al., (2013) also reported that by giving different doses of organic selenium from 100$400 \mu \mathrm{g} / \mathrm{kg}$ of the diet on the commercial broiler birds didn't find any significant difference among the groups where Rajashree et al., (2014) found improvement in the body weight in the organic selenium supplemented groups at a rate of 0.3 to $0.5 \mathrm{ppm}$ than inorganic selenium supplementation and control groups in commercial broiler breeder birds at $29^{\text {th }}$ and $34^{\text {th }}$ week of age but not in $39^{\text {th }}$ week. In the present experiment no change in the body weight was seen as these birds have attended more than 40 weeks of age.

\section{Laying performance}

The egg laying performance of the breeder birds was between 55 to $60 \%$ throughout the experimental period without any effect of the selenium supplementation. Ort et al., (1978) by feeding sodium selenite from 0.1 to $5 \mathrm{ppm}$ didn't find any change in the egg production performance.

Rajashree et al., (2014) didn't find any improvement of egg production performance at $29^{\text {th }}$ wk but higher egg production was seen in $34^{\text {th }}$ and $39^{\text {th }}$ week of age with supplementation of organic selenium w.r.t inorganic and control. In the present experiment the birds have already attended peak production that's why the production performance of the breeder birds didn't improve over the weeks. But by feeding selenium the consistency was maintained up to $52^{\text {nd }}$ week. The production level of coloured broiler breeder birds in the present experiment 
is lower than white commercial breeder birds as reported by Rajashree et al., (2014).

\section{Hatchability}

At $40^{\text {th }}$ wk of age the hatchability \%age of the eggs on total egg set basis was 80.462 to $82.79 \%$ in different groups. The hatchability of the birds increases with the feeding of organic selenium at $52^{\text {nd }}$ week of age which was statistically significant with the lower level of inorganic supplemented groups and control. Both the levels of inorganic supplementation (SS-0.3, SS-0.6) the hatchability increases w.r.t. control one. Rajashree et al., (2014) reported that the hatchability improved upon feeding organic selenium at a rate of 0.3 to $0.5 \mathrm{ppm}$ w.r.t. inorganic and control at 34 weeks of age and organic have higher hatchability than control. But Yuan et al., (2011) didn't find any significant effect on hatchability of the Lingnan Yellow broiler breeder by supplementing either inorganic or organic selenium enriched yeast.

Table.1 Proximate composition of experimental rations

\begin{tabular}{|l|c|}
\hline \multicolumn{1}{|c|}{ Proximate composition } & Percentage on DM basis \\
\hline Moisture & 9.24 \\
\hline Crude protein & 18.01 \\
\hline Ether Extract & 4.16 \\
\hline Crude fibre & 4.92 \\
\hline Total ash & 10.54 \\
\hline Acid insoluble ash & 2.66 \\
\hline Nitrogen free extract* & 53.82 \\
\hline Calcium & 2.97 \\
\hline Available phosphorus & 0.57 \\
\hline Metabolisable energy* $(\mathbf{K c a l} / \mathbf{k g})$ & 2805 \\
\hline Lysine & 1.39 \\
\hline Methionine & 0.64 \\
\hline
\end{tabular}

Percentage on DM basis

*Calculated value

Table.2 Selenium sources and levels supplemented in diets $(\mathrm{mg} / \mathrm{kg})$

\begin{tabular}{|c|c|c|c|}
\hline \multirow{2}{*}{ Treatment } & Diet & \multicolumn{2}{|c|}{ Se level (ppm) } \\
\hline Control & Basal diet & Supplemented & Final total \\
\hline SS-0.3 & Basal diet +SS & 0.0 & 0.028 \\
\hline SS-0.6 & Basal diet +SS & 0.6 & 0.315 \\
\hline SY-0.3 & Basal diet +SY & 0.3 & 0.605 \\
\hline SY-0.6 & Basal diet +SY & 0.6 & 0.307 \\
\hline SS-0.3+SY-0.3 & Basal diet +SS+SY & 0.6 & 0.606 \\
\hline
\end{tabular}


Table.3 Effect of selenium sources on body weight, laying performance and hatchability

\begin{tabular}{|c|c|c|c|c|c|c|c|c|}
\hline Weeks & Control & SS-0.3 & SS-0.6 & SY-0.3 & SY-0.6 & $\begin{array}{c}\text { SS-0.3 + } \\
\text { SY-0.3 }\end{array}$ & SEM & p-value \\
\hline \multicolumn{9}{|c|}{ Body weight } \\
\hline $40^{\text {th }}$ & $\begin{array}{c}3135.34 \\
\pm 22.80\end{array}$ & $\begin{array}{c}3158.42 \\
\pm 26.53\end{array}$ & $\begin{array}{c}3133.80 \\
\pm 23.04\end{array}$ & $\begin{array}{c}3088.27 \\
\pm 22.82\end{array}$ & $\begin{array}{c}3009.24 \\
\pm 39.95\end{array}$ & $\begin{array}{c}3244.16 \\
\pm 28.16\end{array}$ & 49.06 & 0.20 \\
\hline $46^{\text {th }}$ & $\begin{array}{c}3259.25 \\
\pm 14.61\end{array}$ & $\begin{array}{c}3095.04 \\
\pm 38.80\end{array}$ & $\begin{array}{c}3157.02 \\
\pm 40.63\end{array}$ & $\begin{array}{c}3262.65 \\
\pm 38.11\end{array}$ & $\begin{array}{c}3263.21 \\
\pm 25.82\end{array}$ & $\begin{array}{c}3184.82 \\
\pm 22.04\end{array}$ & 78.97 & 0.73 \\
\hline $52^{\text {nd }}$ & $\begin{array}{c}3347.06 \\
\pm 24.28\end{array}$ & $\begin{array}{c}3359.13 \\
\pm 33.63\end{array}$ & $\begin{array}{c}3350.13 \\
\pm 46.31\end{array}$ & $\begin{array}{c}3399.03 \\
\pm 43.04\end{array}$ & $\begin{array}{c}3396.34 \\
\pm 38.62\end{array}$ & $\begin{array}{c}3373.84 \\
\pm 43.71\end{array}$ & 56.52 & 0.42 \\
\hline Mean & $\begin{array}{c}3247.22 \\
\pm 18.52\end{array}$ & $\begin{array}{c}3204.20 \\
\pm 22.23\end{array}$ & $\begin{array}{c}3213.65 \\
\pm 32.67\end{array}$ & $\begin{array}{c}3249.98 \\
\pm 31.84\end{array}$ & $\begin{array}{c}3222.93 \\
\pm 35.23\end{array}$ & $\begin{array}{c}3267.61 \\
\pm 26.28\end{array}$ & & 0.176 \\
\hline \multicolumn{9}{|c|}{ Laying performance } \\
\hline $40-42^{\text {nd }}$ & $\begin{array}{l}57.09 \\
\pm 0.71\end{array}$ & $\begin{array}{l}57.57 \\
\pm 0.87\end{array}$ & $\begin{array}{l}58.74 \\
\pm 1.00\end{array}$ & $\begin{array}{l}57.21 \\
\pm 0.65\end{array}$ & $\begin{array}{l}58.32 \\
\pm 0.85\end{array}$ & $\begin{array}{l}58.47 \\
\pm 0.29\end{array}$ & 0.78 & 0.55 \\
\hline $42-44^{\text {th }}$ & $\begin{array}{l}57.46 \\
\pm 0.90\end{array}$ & $\begin{array}{l}57.02 \\
\pm 1.52\end{array}$ & $\begin{array}{l}58.68 \\
\pm 0.22\end{array}$ & $\begin{array}{l}57.79 \\
\pm 0.90\end{array}$ & $\begin{array}{l}57.43 \\
\pm 0.72\end{array}$ & $\begin{array}{l}56.59 \\
\pm 0.22\end{array}$ & 0.89 & 0.65 \\
\hline $44-46^{\text {th }}$ & $\begin{array}{l}55.54 \\
\pm 0.84\end{array}$ & $\begin{array}{l}54.61 \\
\pm 0.44\end{array}$ & $\begin{array}{l}57.31 \\
\pm 0.58\end{array}$ & $\begin{array}{c}56.5 \\
\pm 0.46\end{array}$ & $\begin{array}{l}57.29 \\
\pm 0.68\end{array}$ & $\begin{array}{l}55.54 \\
\pm 0.91\end{array}$ & 0.69 & 0.09 \\
\hline $46-48^{\text {th }}$ & $\begin{array}{l}56.95 \\
\pm 0.63\end{array}$ & $\begin{array}{l}54.59 \\
\pm 0.31\end{array}$ & $\begin{array}{l}56.72 \\
\pm 0.99\end{array}$ & $\begin{array}{l}56.20 \\
\pm 0.21\end{array}$ & $\begin{array}{l}55.04 \\
\pm 0.27\end{array}$ & $\begin{array}{l}55.18 \\
\pm 0.88\end{array}$ & 0.84 & 0.12 \\
\hline $48-50^{\text {th }}$ & $\begin{array}{l}54.94 \\
\pm 1.18\end{array}$ & $\begin{array}{l}54.90 \\
\pm 1.02\end{array}$ & $\begin{array}{l}55.49 \\
\pm 0.52\end{array}$ & $\begin{array}{l}54.68 \\
\pm 1.01\end{array}$ & $\begin{array}{l}54.85 \\
\pm 0.95\end{array}$ & $\begin{array}{l}55.34 \\
\pm 1.17\end{array}$ & 1.03 & 0.99 \\
\hline $50-52^{\text {nd }}$ & $\begin{array}{l}54.40 \\
\pm 1.04\end{array}$ & $\begin{array}{l}55.57 \\
\pm 0.15\end{array}$ & $\begin{array}{l}55.55 \\
\pm 0.51\end{array}$ & $\begin{array}{l}54.94 \\
\pm 0.95\end{array}$ & $\begin{array}{l}56.09 \\
\pm 1.22\end{array}$ & $\begin{array}{l}54.68 \\
\pm 0.12\end{array}$ & 0.44 & 0.09 \\
\hline Mean & $\begin{array}{l}56.06 \\
\pm 0.42\end{array}$ & $\begin{array}{l}55.88 \\
\pm 0.42\end{array}$ & $\begin{array}{l}57.08 \\
\pm 0.40\end{array}$ & $\begin{array}{l}56.22 \\
\pm 0.37\end{array}$ & $\begin{array}{l}56.50 \\
\pm 0.52\end{array}$ & $\begin{array}{l}55.97 \\
\pm 0.39\end{array}$ & & 0.128 \\
\hline \multicolumn{9}{|c|}{ Hatchability } \\
\hline $40^{\text {th }}$ & $\begin{array}{l}80.46 \\
\pm 1.70\end{array}$ & $\begin{array}{l}82.79 \\
\pm 0.71\end{array}$ & $\begin{array}{l}82.48 \\
\pm 0.85\end{array}$ & $\begin{array}{c}81.61^{\mathrm{B}} \\
\pm 1.01\end{array}$ & $\begin{array}{c}81.79^{\mathrm{B}} \\
\pm 0.62\end{array}$ & $\begin{array}{c}81.93^{\mathrm{B}} \\
\pm 0.79\end{array}$ & 0.97 & 0.67 \\
\hline $46^{\text {th }}$ & $\begin{array}{l}82.40 \\
\pm 0.67\end{array}$ & $\begin{array}{l}83.56 \\
\pm 0.47\end{array}$ & $\begin{array}{l}83.05 \\
\pm 0.83\end{array}$ & $\begin{array}{c}84.64^{\mathrm{AB}} \\
\pm 1.06\end{array}$ & $\begin{array}{c}85.48^{\mathrm{AB}} \\
\pm 1.37\end{array}$ & $\begin{array}{c}84.97^{\mathrm{AB}} \\
\pm 1.28\end{array}$ & 0.96 & 0.24 \\
\hline $52^{\text {nd }}$ & $\begin{array}{l}81.63^{c} \\
\pm 2.07\end{array}$ & $\begin{array}{l}83.95^{b} \\
\pm 0.66\end{array}$ & $\begin{array}{c}84.54^{\mathrm{ab}} \\
\pm 0.40\end{array}$ & $\begin{array}{c}86.32^{\mathrm{aA}} \\
\pm 0.87\end{array}$ & $\begin{array}{c}87.15^{\mathrm{aA}} \\
\pm 0.99\end{array}$ & $\begin{array}{c}86.26^{\mathrm{aA}} \\
\pm 0.84\end{array}$ & 0.76 & 0.01 \\
\hline Mean & $\begin{array}{l}81.49^{b} \\
\pm 0.88\end{array}$ & $\begin{array}{c}83.43^{\mathrm{ab}} \\
\pm 0.36\end{array}$ & $\begin{array}{c}83.36^{\mathrm{ab}} \\
\pm 0.44\end{array}$ & $\begin{array}{c}84.19^{\mathrm{ab}} \\
\pm 0.71\end{array}$ & $\begin{array}{l}84.81^{\mathrm{a}} \\
\pm 0.78\end{array}$ & $\begin{array}{c}84.39^{\mathrm{ab}} \\
\pm 0.69\end{array}$ & & 0.003 \\
\hline
\end{tabular}

\section{External egg parameters}

The egg weight of the breeder birds during the experimental periods was between 58 to $62 \mathrm{~g}$. At $52^{\text {nd }}$ week higher level of organic supplementation (SY-0.6 and SS-0.3+SY-0.3) showed significantly higher egg weight than other groups and control. Our findings are in agreement with Rutz et al., (2013) and Skrivan et al., (2006) who found heavier eggs in organic 
selenium supplemented groups than control hence receiving sodium selenite supplemented diets. Pavlovic et al., (2009) found no significant difference in egg weight in the Shaver hens for feeding either inorganic or organic selenium for a period of 16 week.

Rajashree et al., (2014) reported higher egg weight at the organic selenium supplemented groups than inorganic and control birds in the commercial broiler breeder. In the present experiment the egg weight of the coloured birds are higher than the commercial white birds as reported by Pavlovic et al., (2009) and Rajashree et al., (2014).

Other external egg quality parameters like egg length, egg width, shell thickness and shell weight was not significantly different among the inorganic, organic and mixed groups. Paton et al., (2000) reported increasing shell breaking strength of eggs due to feeding selenium enriched yeast while Payne et al., (2005) is opposite. Our results of the shell thickness and shell weight do not vary with the treatment as the birds are in the decline phase of the egg production and lay heavier eggs.

\section{Internal egg parameters}

No significant effect on all internal egg parameters albumen and yolk height, width, weight was seen among the birds due to supplementation of either inorganic or organic selenium. Invernizzi et al., (2013) reported increased egg surface area by feeding both inorganic and organic selenium than the control. But no effect of egg shell breaking strength was also increased with the organic selenium supplemented groups.

From the above experiment it was found that feeding of organic selenium at both the doses to the coloured broiler breeder hens improved the egg hatchability in comparison with inorganic selenium. Therefore it is recommended that $0.3 \mathrm{ppm}$ of organic selenium should be supplemented to the broiler breeder hen for achieving optimum.

\section{Acknowledgements}

We duly acknowledge AICRP on Poultry Improvement operated in OUAT, Bhubaneswar for provision of birds and physical facilities to carry out the experiment at their poultry complex.

\section{References}

Duncan, D.B. 1955. Multiple ranges and multiple F test. Biometric, 11: 1 - 42.

Edens, F.W. 1996. Organic selenium: From feathers to muscle integrity to drip loss. Five years onward: No more selenite In: Lyons, T.P., Jacques and K.A. (Eds.), Biotechnology in the Feed Industry: The Living Gut. Nottingham University Press, Nottingham NG 110 AX, United Kingdom. Proceedings $12^{\text {th }} \quad$ Alltech Annual Symposium, 12: 165-185.

Edens, W.F. 2002. Practical applications for selenomethionine: broiler breeder reproduction, in: Lyons TP \& Jacques KA (Eds). Nutritional Biotechnology in the Feed and Food Industries 29-42 (Nottingham, Nottingham University Press).

Federal Register. 2000. Food additive permitted in feed and drinking water: selenium yeast. Fed. Reg. 65(109): 3583-3582.

Finch, J.M. and Turner, R.J. 1996. Effects of selenium and vitamin $\mathrm{E}$ on the immune responses of domestic animals, Research in Veterinary Science, 60: 97-106. doi:10. 1016/S0034-5288(96)90001-6.

Invernizzi, G., Agazzi, A., Ferroni, M., Rebucci, R., Fenelli, A., Baldi, A., DellOrto, V. and Savoini, G. 2013. Effects of inclusion of selenium-enriched yeast in the diet of laying hens on performance, egg shell quality, and selenium tissue deposition. Italian Journal of Animal Science. 2013. 11:e1 doi:10.4081/ijas.2013.e1.

Mahan, D.C. 1995. Selenium metabolism in animals: What role does selenium yeast have? Biotechnology in the feed industry. Proceedings of 11th from Alltech's Annual Symposium, (AAS'95), Nottingham, Nottingham University Press. Pp. 257-267. 
Ort, J.F. and Latshaw, J.D. 1978. The toxic level of sodium selenite in the diet of laying chickens. The Journal of Nutrition, 108(7): 1114-1120.

Paton, N.D. and Cantor, A.J. 2000. Effect of dietary selenium source, level of inclusion and length of storage on internal quality and shell strength of eggs; Poultry Science 79(1): 75.

Patterson, E.L., Milstrey, R. and Stokstad, E.L.R. 1957. Effect of selenium in preventing exudative diathesis in chicks. Proceedings of the Society for Experimental Biology and Medicine, 95: 617-620.

Pavlovic, Z., Miletic, I., Jokic, Z. and Sobajic, S. 2009. The effect of dietary selenium source and level on hen production and egg selenium concentration. Biological Trace Element Research, 131: 263-270.

Payne, R.L. and Southern, L.L. 2005. Comparison of inorganic and organic selenium sources of broilers. Poultry Science, 84: 898-902.

Payne, R.L., Lavergne, T.K. and Southern, L.L. 2005. Effect of inorganic versus organic selenium on hen production and egg selenium concentration; Poultry Science. 84: 232-237. doi:10.1093/ps/84.2.232.

Rajashree, K., Muthukumar, T., and Karthikeyan, N. 2014. Comparative study of the effects of organic selenium on hen performance and productivity of broiler breeders; British Poultry Science, 55(3): 367-374.

Rao, S.V.R., Prakash, B., Raju, M.V.L.N., Panda, A.K., Poonam, S. and Murthy, O.K. 2013. Effect of supplementing organic selenium on performance, carcass traits, oxidative parameters and immune responses in commercial broiler chickens; Asian
Australian Journal of Animal Science. 26: 247-252.

Rutz, F., Pan, E.A., Xavier, G.B., Anciuti, M.A. 2003. Meeting selenium demands of modern poultry: Responses to Sel-Plex ${ }^{\circledR}$ organic selenium in broiler and breeder diets.147-161 in Proc. 19th Alltech's Annual Symp., Nottingham, UK.

Skrivan, M., Simane, J., Dlouha, G., Doucha, J. 2006. Effect of dietary sodium selenite, Se enriched yeast and Se-enriched Chlorella on egg Se concentration, physical parameters of eggs and laying hen production; Czech Journal of Animal Science. 51: 163-167.

Snedecor, G. W. and Cochran, W. G. 1994. Statistical Methods. 8th edn. Iowa State University Press, London.

Surai, P.F. 2000. Effect of selenium and vitamin E content of the maternal diet on the antioxidant system of the yolk and the developing chick; British Poultry Science, 41: 235-243. doi:10.1080/713654909.

Torrent, J. 1997. Selenium yeast and pork quality. In: Biotechnology in the Feed Industry. TP Lyons and KA Jacques (eds), Nottingham Univ. Press, Nottinghan, UK. Pp. 161.

Yoon, I., Werner, T.M., and Butler, J.M. 2007. Effect of source and concentration of selenium on growth performance and selenium retention in broiler chickens; Poultry Science. 86: 727-730.

Yuan, D., Zhan, X and Wang, Y. (2011) Effects of selenium sources and levels on reproductive performances and selenium retention in broiler breeder, egg, developing embryo, and 1-day-old chick. Biological Trace Element Research, 144: 705-714.

\section{How to cite this article:}

Mohanty, P.P., N. Panda, R.K. Swain, N.C. Behura, P. Ray, A.K. Sethi and Panigrahi, S. 2018. A Comparison between Organic and Inorganic Selenium: 1. Effect on Body Weight, Laying Performance, Hatchability in Broiler Breeder. Int.J.Curr.Microbiol.App.Sci. 7(05): 173-179. doi: https://doi.org/10.20546/ijcmas.2018.705.022 